Jean G. Boogaerts MD PhD, Noëlle D. Lafont MD, Hongwen Luo PhD, Franz J. Legros PhD

\section{Plasma concentrations of bupivacaine after brachial plexus administration of liposome-associated and plain solutions to rabbits}

caine were lower during the first ten minutes $(P<0.05)$, and higher after $24 \mathrm{hr}(P<0.05)$. Radioactivity decreased between 4 and $24 \mathrm{hr}$ in the BP group and between one and two days in the BP-MLV population. It is concluded that elevated plasma drug concentrations were maintained for longer with BP-MLV than with BP. This could prolong the action of the local anaesthetic through a slow release.

La bupivacaïne a été associée à des liposomes multilamellaires, composés de phosphatidylcholine et cholestérol (rapport molaire 4:3) dans le but de modifier les concentrations plasmatiques de l'anesthésique local après administration au niveau du plexus brachial du lapin. Sous anesthésie générale, un premier groupe (BP) de six lapins a reçu une injection plexique de $1 \mathrm{ml}$ de bupivacaïne commerciale à $0,25 \%$ sans adrénaline. Le second groupe (BP-MLV) a reçu $1 \mathrm{ml}$ de bupivacaïne liposomale à 0,25\%. De la bupivacaine tritiée a été utilisée comme marqueur. Le plexus brachial a été repéré à laide d'un stimulateur de nerf. Linjection des solutions anesthésiques fit disparaitre les réponses musculaires dans la patte. Les concentrations artérielles de bupivacaïne ont été mesurées à des temps différents (de 5 à 240 minutes et après 24 heures) par comptage de la radioactivité plasmatique et exprimées en $\mu \mathrm{g} \cdot \mathrm{ml}^{-1}$. Dans le groupe $M L V$, des prélèvements supplémentaires ont été pratiqués après 48 et $72 \mathrm{hr}$. Les deux courbes plasmatiques montrent un plateau identique $\left(0,2 \mu \mathrm{g} \cdot \mathrm{ml}^{-l}\right)$, qui est atteint après cinq minutes dans le groupe $B P$ et après 90 min dans le groupe $B P-M L V$. Dans ce dernier groupe, la concentration plasmatique de bupivacaïne était plus basse durant les dix premières minutes $(P<0,05)$ et plus élevée après $24 \mathrm{hr}(P<0,05)$. La concentration plasmatique de bupivacaïne diminuait entre 4 et $24 \mathrm{hr}$ dans le groupe BP et après un à deux jours dans le groupe $B P-M L V$. Lassociation de la bupivacaïne à des MLV pourrait prolonger la durée d'action de la bupivacaïne administrée au niveau du plexus brachial par le biais d'une libération progressive de l'anesthésique local. 
Liposomes have been used as drug carriers in an attempt to control the delivery of biologically active agents which can lead to prolonged effect and reduced toxicity. ${ }^{1,2}$ Specifically, local anaesthetics have been encapsulated into liposomes with the aim of obtaining a longer duration of action or a reduction in circulating plasma concentrations. ${ }^{3-7}$

Bupivacaine, a long-acting amino-amide local anaesthetic, has been associated to multilamellar liposomes (MLV). ${ }^{5,7}$ Preliminary animal studies indicated that epidurally injected MLV act as a depot formulation, releasing bupivacaine in a controlled fashion and ensuring a low, constant and prolonged plasma concentration. ${ }^{7}$ Boogaerts $e t$ al. have shown that the liposomal formulation of $0.5 \%$ bupivacaine increases the duration of postoperative analgesia in humans without motor blockade or adverse side effects. $^{5}$

The present study was undertaken to compare the plasma concentrations of bupivacaine after injection of plain and liposomal formulations of bupivacaine into the rabbits' brachial plexus. The axillary route was selected because it represents the easiest technique of brachial plexus blockade in the rabbit.

\section{Methods}

\section{Liposomal encapsulation of bupivacaine}

The method of bupivacaine association to liposomes has been described in detail elsewhere. ${ }^{8}$ Bupivacaine was inserted into liposomes made of egg phosphatidylcholine (Egg Pc, Fraction VII, Sigma, St. Louis, MO) and cholesterol (Ch, Sigma) in a molar ratio $4: 3$. The total weight of lipids was $60 \mathrm{mg}$. Lipophilic bupivacaine was obtained from the chloride solution (bupivacaine hydrochloride, Marcaine ${ }^{\circledR}$, Astra Nobel Pharma) by adding $\mathrm{KOH}$ to a $\mathrm{pH}>10$. The precipitate was filtered and dissolved in chloroform. The chloroform/ bupivacaine solution containing $2.5 \mathrm{mg}$ of drug was mixed homogeneously in a glass vial with $\mathrm{Egg} \mathrm{Pc}$ and $\mathrm{Ch}$, both dissolved in the same organic solvent and $0.001 \mathrm{mCi}{ }^{3} \mathrm{H}$-bupivacaine in ethanol ( ${ }^{3} \mathrm{H}$-bupivacaine, $0.1 \mathrm{mCi} \cdot \mathrm{ml}^{-1}$, Institut des Radio-Eléments, Fleurus, Belgium) were added as a marker. Tritium labelling of bupivacaine was performed on a methyl group associated to the benzoyl lipophilic moiety of the molecule. Evaporation of the solvent under a nitrogen atmosphere resulted in the formation of a lipid film of Egg Pc, $\mathrm{Ch}$, lipophilic bupivacaine and its radionuclide. This film was kept overnight in a vacuum lyophilizer to remove the last traces of chloroform.

One milliliter phosphate buffer, $\mathrm{pH} 8.1$, brought to an osmolality of $280 \mathrm{mOsm} \cdot \mathrm{kg}^{-1} \mathrm{H}_{2} \mathrm{O}$ by the addition of $\mathrm{NaCl}$, was added to the lipid film, and multilamellar vesicles (MLV) were formed by vortexing until the film completely disappeared. The measured osmolality and viscosity of both plain and liposomal solutions were identical. The liposomal preparations were kept at $4^{\circ} \mathrm{C}$ until use.

\section{Injection into the brachial plexus of rabbits}

After approval of the Institutional Animal Investigation Committee, New Zealand male albino rabbits (Rechtpersoonlijkheid Rijksstation, Ghent, Belgium) weighing about $2.5 \mathrm{~kg}$ were anaesthetized by $\mathrm{im}$ injection of 0.1 $\mathrm{mg} \cdot \mathrm{kg}^{-1}$ Hypnorm $^{\circledR}$, an association of fluanisone and fentanyl (Janssen Pharmaceutica, Beerse, Belgium). Anaesthesia lasted for about two hours and if a longer duration was required further Hypnorm $0.05 \mathrm{mg} \cdot \mathrm{kg}^{-1}$ was administered.

Two groups of six rabbits were studied. The first group received an injection of $1 \mathrm{ml}$ bupivacaine $0.25 \%$ without adrenaline (Marcaine ${ }^{\circledR}$, Astra Nobel Pharma) with 0.001 $\mathrm{mCi}{ }^{3} \mathrm{H}$ bupivacaine as a marker and the second group received the same dose of bupivacaine associated to MLV.

The axillary region was prepared with rabbits in the supine position. A ground electrode was attached to the opposite paw and connected to the output pole of a peripheral nerve stimulator (Stimuplex ${ }^{\circledast}$, B. BraunMelsungen AG, FRG). A 23-gauge insulated needle (Pole Needle ${ }^{\circledR}$, Equip Medical, Holland) was connected to the other pole. The brachial plexus was located using the axillary approach. The needle was used as a seeking electrode to elicit motor movement in the paw. Flexion of the distal part of the paw was the defined end point. The output from the stimulator was set at the lowest milliamperage $(0.1 \mathrm{~mA}$ at $1 \mathrm{~Hz})$ and the seeking needle was then advanced until motor activity was evident. Once the nerves were located, the local anaesthetic solution was injected.

Bupivacaine plasma concentrations were determined by counting the radioactivity ( $\mathrm{Rad}$ ) in arterial blood in both groups. A 24-gauge needle was inserted into the rabbit ear artery. Two milliliters of blood were collected in heparinized tubes at various times following injection for $24 \mathrm{hr}$. In the MLV bupivacaine group, two additional samples were obtained after 48 and $72 \mathrm{hr}$. The blood samples were centrifuged at 3,500 g for 15 min using a bench centrifuge (Beckman GPR; Palo Alto, CA) and $0.5 \mathrm{ml}$ plasma samples were mixed with $1 \mathrm{ml}$ tissue solubilizer (Soluene ${ }^{\circledR}$, Packard) in Packard glass vials. Ten milliliters scintillation cocktail (Instafluor ${ }^{\circledR}$, Packard) were added and beta counting was performed using a Rackbeta ${ }^{\circledR}$ Counter (Pharmacia, Uppsala, Sweden). Plasma concentrations of bupivacaine expressed in $\mu \mathrm{g} \cdot \mathrm{ml}^{-1}$ were calculated as follows:

( $R a d$ in $1 \mathrm{ml}$ plasma/total Rad injected) total $\mu \mathrm{g}$ bupivacaine injected. 
The method was sensitive from cpm countings corresponding to $0.02 \mu \mathrm{g} \cdot \mathrm{ml}^{-1}$ and reproducible from 0.05 to $0.7 \mu \mathrm{g} \cdot \mathrm{ml}^{-1}$.

After awakening from general anaesthesia, the animals were put on the floor and an attempt was made to encourage them to walk.

\section{Statistical analysis}

The results are expressed as the mean \pm SD. Statistical significance between groups was determined using ANOVA. $P<0.05$ was considered statistically significant.

\section{Results}

The axillary injection prevented the motor response of the paw produced by nerve stimulation within a few seconds in using BP and BP-MLV.

Arterial plasma bupivacaine concentrations are shown in the Figure. The highest concentrations averaged $\mathbf{0 . 2}$ $\mu \mathrm{g} \cdot \mathrm{ml}^{-1}$ in both experimental groups. Radioactivity was detected in plasma after five minutes in both groups but the plasma concentration profiles were different. In the BP group, the plasma curves showed a plateau which was reached after five minutes. For the BP-MLV group the plasma concentration increased gradually during the first $90 \mathrm{~min}$ and was followed by a prolonged plateau phase.

During the first ten minutes, plasma concentrations were higher after administration of the plain solution $(P$ $<0.05$ ). The mean plateau levels were $0.214 \pm 0.031$ $\mu \mathrm{g} \cdot \mathrm{ml}^{-1}$ in the BP group and $0.204 \pm 0.014 \mu \mathrm{g} \cdot \mathrm{ml}^{-1}$ in the BP-MLV group (NS).

The duration of the plateau phases was different: in the BP group, the plasma concentration decreased between four and $24 \mathrm{hr}$ after administration. After $24 \mathrm{hr}$, the plasma concentrations were higher in the BP-MLV group $(P<0.05)$. Plasma drug concentrations decreased thereafter to $0.118 \pm 0.009 \mu \mathrm{g} \cdot \mathrm{ml}^{-1}$ after $48 \mathrm{hr}$ and $0.085 \pm 0.012 \mu \mathrm{g} \cdot \mathrm{ml}^{-1}$ after $72 \mathrm{hr}$ in this group.

After awakening from general anaesthesia, no motor blockade of the paw was observed in either group. Sensory blockade was not evaluated.

\section{Discussion}

Liposomal bupivacaine prevented the nerve motor response of the paw within a few seconds of injection which indicated that the anaestheic effect of this formulation was preserved. The minimum stimulating current $(0.1$ MA) used for location of the plexus using insulated needle confirmed that the injections were made very close to the nerves in the axillary sheath. ${ }^{10}$ The low concentration of bupivacaine used $(0.25 \%)$ explains the absence of motor blockade at the time of awakening of the animals. Association of bupivacaine to multilamellar liposomes modified its pharmacokinetic profile after injec-

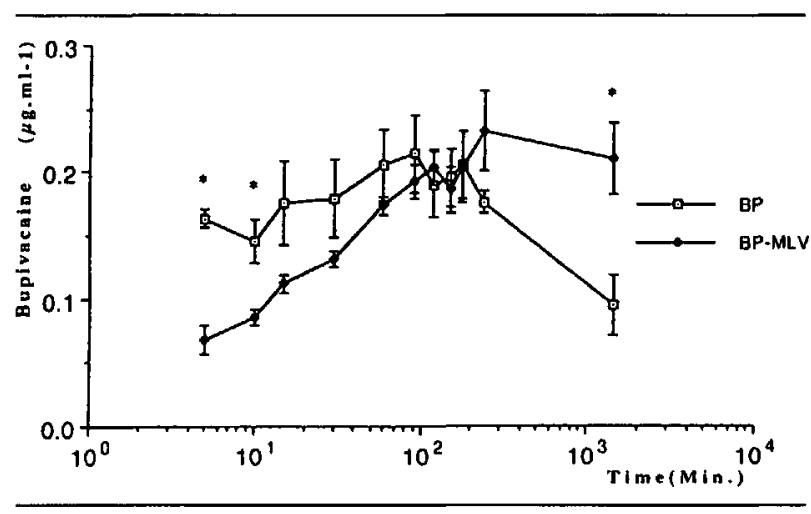

FIGURE Time course (Log. min) of plasma concentrations of bupivacaine $\left(\mu \mathrm{g} \cdot \mathrm{ml}^{-1}\right)$ in two groups of six rabbits after injection into the axillary brachial plexus of plain (BP) or liposome-associated bupivacaine (BP-MLV). Mean $\pm \mathrm{SD} . * P<0.05$.

tion into the rabbit brachial plexus. The plasma plateau phase, commonly observed following this mode of administration, occurred later using BP-MLV than with BP. " This might be attributed to a delay in the vascular resorption of bupivacaine molecules released from the phospholipid vesicles.

The rate of local anaesthetic absorption from an injection site is dependent upon the site of injection, the dose of local anaesthetic and the pharmacological profile of the drug. ${ }^{11,12}$ In the present experiments, the same doses of bupivacaine, free or associated to liposomes, were administered.

The low vascularity and the presence of varying amounts of adipose tissue in the brachial plexus region account for the rather slow absorption of local anaesthetics from this site. ${ }^{13}$ The adipose tissue may act as a depot for these drugs and will tend to delay their vascular resorption. ${ }^{14,15}$ It is likely that a portion of the administered dose was absorbed by the fat ${ }^{16}$ and this could explain the low plasma concentrations of bupivacaine. The maximal concentrations averaged $0.2 \mu \mathrm{g} \cdot \mathrm{ml}^{-1}$ in the plateau phase encountered with the BP and BP-MLV solutions.

Only the free fraction of bupivacaine is able to diffuse in the blood vessels. A progressive and sustained release of bupivacaine from MLV could account for an interstitial constant free fraction of local anaesthetic which ensured delay in duration of plasma levels. Liposomes would form an artificial local depot of bupivacaine releasing their content slowly. This property could account for the prolonged plateau phase to $48 \mathrm{hr}$ with the liposomal formulation.

The present plasma measurement of bupivacaine was based upon total ${ }^{3} \mathrm{H}$-bupivacaine radioactive counting. Tritium was chosen because it represents a stable isotope with a half-life of $12 \mathrm{yr}$. Circulating bupivacaine is rapidly 
catabolized into more polar compounds by the liver. ${ }^{9-11}$ The radioactivity measured in the rabbit plasma thus involved bupivacaine and catabolic products, and did not represent a true mirror of local anaesthetic concentration. Tritium labelling of bupivacaine was performed on a methyl group associated to the benzoyl lipophilic moeity of the molecule. Hepatic biotransformation of the local anaesthetic does not alter this part of the molecule, " as 2,6-Xylidine represents one of the final catabolites of bupivacaine, and the tritium radioactivity counted in the plasma necessarily involves this biotransformation product. Further specification of the chemical composition of plasma radioactivity needs studies using qualitative chromatography detection of circulating bupivacaine and known metabolites. The main purpose of this experiment was to compare the plasma levels of bupivacaine using the two formulations of bupivacaine and not a pharmacokinetic study. The feasibility of a stable isotope method has been demonstrated in a similar experiment. ${ }^{17}$

In conclusion, association of bupivacaine to MLV maintains elevated plasma concentrations of bupivacaine for longer than after a plain solution after axillary administration to rabbits. This raises the possibility of prolonging local anaesthetic action by slow release of the drug.

\section{Acknowledgements}

The authors wish to thank P. Thys MD, and C. Ravaioli, secretary, for help in the preparation of the manuscript.

\section{References}

1 Ranade VV. Drug delivery systems. 1. Site-specific drug delivery using liposomes as carriers. J Clin Pharmacol 1989; 29: 685-94.

2 Boogaerts J, Declercq A, Lafont N, et al. Toxicity of bupivacaine encapsulated into liposomes and injected intravenously: comparison with plain solutions. Anesth Analg 1993; 76: 553-5.

3 Stozek $T$, Krowczynski $L$. The effect of entrapment of procaine hydrochloride in liposomes on its local anesthetic action. Pharmazie 1989; 44: 466-8.

4 Gesztes $A$, Mezei $M$. Topical anesthesia of the skin by liposome-encapsulated tetracaine. Anesth Analg 1988; 67: 1079-81.

5 Boogaerts JG, Lafont ND, Legros FJ. Epidural administration of liposomal bupivacaine for the management of postsurgical pain. Br J Anaesth 1993; 70: A200.

6 Mashimo T, Uchida I, Pak M, et al. Prolongation of canine epidural anesthesia by liposome encapsulation of lidocaine. Anesth Analg 1992; 74: 827-34.

7 Legros F, Luo H, Bourgeois P, Lafont N, Boogaerts J. Influence of different liposomal formulations on pharmacokinetics of encapsulated bupivacaine. Anesthesiology 1990; 73: A851.
8 Legros F, Ruysschaert JM. Composition pharmaceutique contenant un anesthésique local et/ou un analgésique central encapsulé dans des liposomes multilamellaires. European Patent $0233100 \mathrm{Bl}, 1991$.

9 Covino BG, Vassallo HG. Local Anesthetics. Mechanisms of Action and Clinical Use. New York: Grune and Stratton, 1976; 115.

10 Ford DJ, Pither C, Raj PP. Comparison of insulated and uninsulated needles for locating peripheral nerves with a peripheral nerve stimulator. Anesth Analg 1984; 63: 925-8.

11 Tucker GT, Mather LE. Properties, absorption, and disposition of local anesthetic agents. In: Cousins MJ, Bridenbaugh PO (Eds.). Neural Blockade in Clinical Anesthesia and Management of Pain. Philadelphia: JB Lippincott, 1988; 47-110.

12 Widman B. Plasma concentration of local anaesthetics agents in regard to absorption, distribution and elimination, with special reference to bupivacaine. $\mathrm{Br} \mathrm{J}$ Anaesth 1975; 47: 231-6.

13 Vester-Andersen T, Christiansen A, Hansen A, Sørensen $M$, Meisler $C$. Interscalene brachial plexus block: area of analgesia, complications and blood concentrations of local anesthetics. Acta Anaesthesiol Scand 1981; 25: 81-4.

14 Tuominen. M, Rosenberg PH, Kalso E. Blood levels of bupivacaine after single dose, supplementary dose and during continuous infusion in axillary plexus block. Acta Anaesthesiol Scand 1983; 27: 303-6.

15 Rosenberg PH, Pere P, Hekali R, Tuominen M. Plasma concentrations of bupivacaine and two of its metabolites during continuous interscalene brachial plexus block. $\mathrm{Br} \mathrm{J}$ Anaesth 1991; 66: 25-30.

16 Tucker GT. Pharmacokinetics of local anaesthetics. $\mathrm{Br} \mathrm{J}$ Anaesth 1986; 58: 717-31.

17 Burm AGL. Clinical pharmacokinetics of epidural and spinal anaesthesia. Clin Pharmacokinet 1989; 16: 283-311. 